Français, anglais et allemand: trois langues rivales entre 1850 et 1945. French, English and German: three languages in competition between 1850 and 1945

\title{
English and/or French at Higher Secondary Schools for Girls (1870-1900) in Germany: Contrast or Complement?
}

\section{Sabine Doff}

\section{(2) OpenEdition Journals}

\section{Édition électronique}

URL : https://journals.openedition.org/dhfles/4012

DOI : 10.4000/dhfles.4012

ISSN : 2221-4038

\section{Éditeur}

Société Internationale pour l'Histoire du Français Langue Étrangère ou Seconde

\section{Édition imprimée}

Date de publication : 1 décembre 2014

Pagination : 49-63

ISSN : 0992-7654

Référence électronique

Sabine Doff, «English and/or French at Higher Secondary Schools for Girls (1870-1900) in Germany:

Contrast or Complement? », Documents pour l'histoire du français langue étrangère ou seconde [En ligne], 53 | 2014, mis en ligne le 05 septembre 2017, consulté le 28 mai 2021. URL : http:// journals.openedition.org/dhfles/4012; DOI : https://doi.org/10.4000/dhfles.4012

Ce document a été généré automatiquement le 28 mai 2021 


\title{
English and/or French at Higher Secondary Schools for Girls (1870-1900) in Germany: Contrast or Complement? ${ }^{1}$
}

\author{
Sabine Doff
}

\section{Introduction}

1 A well-known $19^{\text {th }}$ century work on the psychology of gender-specific teaching methodology clearly indicates a specific affinity of the female gender with modern languages:

The female linguistic memory related to words and word forms in foreign languages is remarkably well developed. It is a well-known fact that girls acquire modern languages faster than men and boys. The latter usually achieve less in English and French even if they are equally gifted ${ }^{1}$. (Wendt 1887: 111)

Wendt's words sum up main background features of the key hypothesis of this paper, that modern languages, in particular English, played an influential role in the constitution of higher secondary (that is post-elementary) schools for girls in $19^{\text {th }}$ century Germany (Doff 2002: 2005). A considerable number of experts like Wendt and key figures of the Reform Movement, who often taught at secondary schools for girls for at least a few years, ${ }^{2}$ obviously followed the idea that girls were especially gifted for learning modern languages, rather than maths or the classical languages which were thought to "overburden" and be of no use at all to them (see below). Thus English and French, two subjects which were hardly represented in the secondary school tradition for boys (the Gymnasium), dominated private and public institutions of higher secondary education for girls. In this context, it is hardly surprising that a distinct gender-specific methodological approach of teaching modern languages developed eventually (Doff 2002: 396-400). 
3 Although they had existed since the beginning of the century, the number of higher secondary schools for girls in Germany in the private as well as in the state sector increased significantly in the second half of the $19^{\text {th }}$ century. Traditional schools for higher secondary education for girls had existed in Germany since the $17^{\text {th }}$ century; yet these institutions were not run by the state and aimed at a training of practical skills for so-called "higher daughters" ("höhere Töchter", meaning daughters from well-off families) in the fields of languages (in particular conversation in French), music and housekeeping rather than at a higher secondary education by academic standards. This changed with the last third of the $19^{\text {th }}$ century, when public calls for "proper" higher secondary education enabling girls to attend university increased (Albisetti 1998; Doff 2002). A milestone in this development was the so called Weimarer Konferenz (Weimar Conference) of 1872, where women and in particular men from all parts of Germany representing this school type got together officially for the first time to discuss questions of secondary education for girls provided by the state. The date is often taken to mark the official beginning of the institutionalization of the higher secondary school state system for girls in Germany (Albisetti 1988; Doff 2002). Since then, not only the number of schools but also of published contributions discussing related questions, for example in educational journals and school programs (Schulprogrammschriften) increased substantially. This development came to a temporary end in 1908 with the extensive reform of the higher secondary educational system for girls in Prussia.

The most distinctive feature which was commonly used during this period to characterize higher secondary schools for girls (as compared to middle schools for girls or higher secondary schools for boys) was the teaching of at least two modern languages, usually French and English: "Learning one foreign language hardly suffices anywhere; in particular girls claiming certain educational standards ask for French and English" (Strack 1879: 3)3. Against this backdrop the salient role of the modern languages as school subjects in this context becomes clear: they were the feature which distinguished higher secondary education for girls and boys but at the same time helped to provide the former with an equivalent status to the latter.

5 As the quotation from Wendt (1887) above shows, some of the main motives for this specific profile were gender-related. They were controversially discussed in a fierce and often emotionally heated public debate which is analysed in more detail in section 2 below. Whereas for most of the $19^{\text {th }}$ century, French was the modern language dominating in higher secondary education for girls, this started to change with the institutionalization of the higher secondary school system in the last quarter of the century. This development is reflected in a parallel public debate on the relative merits of English and French, some highlights of which are discussed in section 3.

\section{Modern languages and higher secondary schools for girls}

6 Gender-related motives for teaching modern languages often came up in the public debate concerning the institutionalization of the higher secondary school system for girls. It is a remarkable though hardly surprising fact that gender-related argumentation hardly ever appears in the corresponding debate related to the higher secondary school system for boys. For most of the $19^{\text {th }}$ century this debate was dominated by arguments related to the usefulness of modern language teaching, but in 
the last quarter of the century arguments in favour of modern language teaching related to Bildung (that is educational reasons) took over. The changing character of this debate is mirrored in the parallel discussion of the general public state school system in Germany: in the beginning this discussion concentrated on defining higher versus middle secondary schools for girls; the main difference between both was finally settled by two (English and French) versus one (English) foreign language. Moreover, the debate soon focused on establishing higher secondary schools for girls as equal to higher secondary schools for boys (where traditionally the classical languages played an important role); in order to achieve this, the educational value (Bildungswert) of the modern languages (rather than their usefulness) had to be stressed. ${ }^{1}$

7 Before the beginning of the $20^{\text {th }}$ century (and often for longer) the moderate liberal approach saw education of boys and girls as different but equal. This view was shared by a majority of moderate reformers, whose number grew slowly but steadily; it was also supported by the conservative (and dominant) wing of the German women's movement around Helene Lange (1848-1930). The following gender-related arguments were used by advocates of modern language teaching at higher secondary schools for girls to stress the distinct gender-related character of this school type. Later, that is when more progressive ideas supporting identical education for girls and boys were gaining ground, these arguments were often used against women and higher female secondary education.

\subsection{Gender-related arguments}

8 One of the most common gender-related arguments in this debate was that modern languages were easier to learn than classical languages (i.e. Greek and Latin) and thus minimized the threat of "overburdening" the girls (Maass 1872: 219). Moreover, they more or less guaranteed quick success in learning which was crucial especially for less gifted girls who would attend higher secondary schools along with the more gifted (Kalepky 1890: 8).

9 Furthermore, it was argued that girls were especially talented in learning modern languages, as the introductory quotation of this paper illustrates. The special "female" talent becomes evident, for example, in women's speech rate - worldwide, as the same author at least suspected:

Surely women's fast speech rate also becomes evident in Mongolian and AfroAmerican people as well as in Polynesia and Melanesia. Most likely the women of Australians and bushmen behave in the same way since their strange liveliness and excessive emotional constitution perfectly match the character of the female gender ${ }^{2}$. (Wendt 1887: 71)

10 This particular character of the female gender and its consequences for modern language teaching were discussed in more detail in a popular encyclopedia at the beginning of the $19^{\text {th }}$ century:

Warmth and friendliness (Gemüthlichkeit) are typical features in femininity and nature tries to keep anything away from the female character which might destroy its natural constitution. This is the reason why grammar and mathematics mean neither fortune nor bliss for girls; also with regard to languages they simply do not favor analytical approaches. This is why language teaching for girls should be designed in a more lively way. And since they should never grasp rules systematically, these should be depicted as vividly as possible. But this can of course only happen in the mother tongue, and maybe also in a foreign one, but of 
course only in a living language which is learned accordingly ${ }^{3}$. (Reuter 1811:

183-184) their partial mind but also their gender-specific character which made girls particularly gifted for learning modern languages. Not surprisingly - at least from our perspective today -, these arguments soon turned against the very gender they were originally supposed to be in favor of.

\subsection{Arguments related to usefulness and Bildung}

Apart from gender-specific reasons, there were also other arguments which spoke in favour of teaching two modern languages at higher secondary schools for girls. As pointed out before, these can be divided into two categories, usefulness and Bildung ("general education"). Based on the earlier was, for example, the argument that the opportunities for girls and women to actually use the languages they learned at school in "real life" was steadily increasing: even if the number of jobs available for them (for example, as teachers) was still limited, they could foster their language proficiency by reading books and journals without translations. The growing influence of the English language in particular on German culture and literature has to be mentioned in this context as well as the important and steadily growing trade relationships between Britain and Germany. Moreover, it became significantly easier to travel abroad in the course of the $19^{\text {th }}$ century, an opportunity which many so-called "higher daughters" (see above) took as a welcome break between school and marriage (Benecke 1868: 36; Ritter 1897: 439; Haas 2000). It also became common for future female teachers to spend a considerable period of time abroad in order to qualify for teaching modern languages in the higher secondary educational German system, which formally did not admit women into regular high school teacher training courses for most of the $19^{\text {th }}$ century.

For the school type "higher secondary girls school" the teaching of two modern languages became the distinct feature which characterized them against elementary education on the one hand and against higher secondary education for boys on the other: "With regard to methodology and limitation of certain contents [the higher secondary school] for girls resembles elementary school, with regard to foreign language teaching, however, [...] it is closer to higher secondary schools for boy" (Dammann 1885: 67). ${ }^{5}$ important for reasons discussed above. A typical quotation highlights the change of direction in this debate and mentions a number of arguments which often surfaced in this context:

Documents pour l'histoire du français langue étrangère ou seconde, 53 | 2014 
Languages make us aware of the development of human imagination, humankind's rich terminology and the colors of various terms, their inter-relatedness and their imaginary power. Comparing various languages can create an awareness of how one and the same image was conceptualized by various peoples. Moreover speaking and listening to languages, in particular foreign languages, offers a perfect training of the speaking and listening organs as well as of the ability to learn ${ }^{6}$. (Maass 1872: 214)

16 Another of the key arguments which came up repeatedly in the debate was the cosmopolitan character of higher secondary education which played a particularly important role in Germany, also for historical reasons: "If we see [...] tolerance as one of the finest features of modern education, it is not feasible any longer nowadays to accept limitations to our own people in any field [...]. The modern individual has to be (and in fact is) a cosmopolitan" (Schumann 1876: 604). ${ }^{7}$ It was obvious even to nonexperts that modern languages were considered to be particularly suitable means to foster this cosmopolitan ideal.

These arguments in the three categories gender, usefulness and Bildung demonstrate that modern languages were a constitutional feature when it came to defining and later to the institutionalization of higher secondary education for girls in Germany in the course of the $19^{\text {th }}$ century. The next part of this paper takes a closer look at the two languages involved.

\section{English and/or French?}

In the tradition of the $18^{\text {th }}$ century and the governesses (see Hardach-Pinke 1993), when French was considered to be the language of the court in particular and of good taste in general, this continued to be the key modern language subject taught at German higher secondary schools for girls well into the $19^{\text {th }}$ century. In the context of the methodological concept highlighted in part 2, however, French was a suitable subject only to a limited extent, mainly due to its grammar which seemed quite complex when compared to other modern languages, in particular English:

It can [...] not be denied that the static, often purely extrinsic rules are nothing but a logical means of education. Moreover, the outstanding gifts of mind typical of female learners (judgement, taste, quick ability to learn) are not fostered by drumming French grammar into them. By overburdening women's minds, which are often less strong than those of men, their development is paralyzed. That means a lot of reading, constant exercise of writing and conversation but grammar only when necessary and rather by exercise than by learning by heart or rule drills ${ }^{1}$. (Horn 1893: 310-311)

Grammar was obviously one of the reasons why English in the course of the $19^{\text {th }}$ century replaced French as the most popular foreign language taught at higher and middle secondary schools for girls. Apart from the grammar, French literature was a problem: there were too few standard works which were regarded as suitable for educating young girls and women since a number of popular literary works in French were considered to promote a superficial and frivolous lifestyle. This is, for example, pointed out by Ackermann (1883: 182) who claims that "French literature next to many fine aspects also contains a lot of superficial features, that namely in more recent publications a certain view of life is presented to us - moreover in a shining way which we would not like to be anchored in German women's minds". ${ }^{2}$ 
But there were also a number of reasons which spoke for French: Apart from its long tradition in the education of the so-called "higher daughters" in Germany, it was considered particularly suitable in terms of higher formal education and taken to be the best replacement for classical languages at higher secondary schools for boys, as Kreyenberg (1887: 88) put it: "French is the Latin of higher secondary schools for girls".

21 The arguments in favor of French were occasionally used against English and vice versa. Due to many similarities with German, quick successes in learning English at the beginning were more or less guaranteed. This matched the increasingly popular didactic principle to proceed from the easier to the more difficult phenomena. Moreover, since logical and formal thinking was not considered to be a strength of the female character anyway, the English language which could be handled with a minimum of grammar seemed an ideal choice in the context of higher secondary education for girls (see, for example, Sander 1889: 126). For practical reasons, it made sense to promote English, the upcoming lingua franca, as the first and dominant modern foreign language at higher secondary schools for girls. But also in terms of Bildung (here: formal education), English was promoted as a first choice for reasons which had been discussed by no one less than Jakob Grimm:

None among all modern languages but English has gained greater power and strength by giving up and shattering all sound laws, by omitting nearly all inflections. It's learnable but not teachable abundance of colours provides for an expressive power which has probably not been gained by any other human tongue before. Its full mental wonderfully fortunate capacity and formation had evolved from a surprising marriage of the two noblest languages of the late Europe ${ }^{4}$. (Grimm 1852: 50)

Next to this special quality resulting from a mixture of Germanic and Romance elements, a number of literary works in English by authors like, for example, Shakespeare, Thomas Milton or Jane Austen were considered excellent choices for teaching more proficient female learners of English; in case a Shakespearian tragedy was regarded as too bloodthirsty, the end was simply rewritten by textbook authors for English language teaching at higher secondary schools for girls (Niemeyer 1794: 173; Gantter \& Wildermuth 1880: 197).

\section{Conclusion}

To sum up, this paper has argued that modern languages played a salient role in constituting higher secondary education for girls in Germany in the course of the $19^{\text {th }}$ century and that a specific didactic approach of teaching English and/or French resulted from this. The reasons for this development can be discussed in the three categories gender, usefulness and Bildung. The teaching of two modern languages at the higher secondary school for girls was a crucial feature which separated this school type from middle schools for girls on the one hand and made it comparable to higher secondary education for boys on the other hand. In this context, English and French were often discussed as contrasts, but in the end, there was a majority of voices which stressed the fact that due to a variety of reasons, some of which were discussed in this paper, French was an ideal complement of English (and vice versa), for example in terms of grammatical and inflectional complexity but also with regard to the specific female "character" which was supposed to influence learning to a considerable extent. 
Whereas contrasting elements of both languages were not denied they were seen as complementing each other in a growing number of cases like the following: "Thus we can see that both languages all in all equal each other regarding their overall educational value. Carried out in a parallel way they complement one another nicely: French provides for intellectual and English for emotional education" (Nimmerjahn 1898: 466). ${ }^{1}$ Thus a combination of the two languages was often considered to be a perfect solution for the higher secondary education of German girls and women.

\section{BIBLIOGRAPHIE}

\section{Primary Sources}

ACKERMANN, Eduard (1883). Der fremdsprachliche Unterricht in der höheren Mädchenschule”. Zeitschrift für weibliche Bildung, 11, 173-184, 217-226.

BENECKE, Albert (1868). “Das Englische auf der höheren Töchterschule”. Stoa. Zeitschrift für die Interessen der höheren Töchterschulen, 1, 35-51, 239-244, 380-386.

DAMMANN, Adolf (1885). Die höhere Mädchenschule. Ein Beitrag zur Reform des höheren Mädchenschulwesens. Teil 1: Aufgabe und Ziel, Organisation und Lektionsplan, Stellung und Personal der höheren Mädchenschule. Berlin: Oehmigke.

GANTTER, Ludwig \& WILDERMUTH, Johann David (1880). "Englische Sprache”. In Karl Adolf Schmidt (dir.). Encyclopädie des gesammten Erziehungs- und Unterrichtswesens, bearbeitet von einer Anzahl Schulmänner und Gelehrten. Volume 2: Dankbarkeit - Globus. Second edition. Gotha: Besser, 193-204.

GRIMM, Jakob (1852). Über den Ursprung der Sprache. Berlin: Dümmler.

HORN, F. (1893). “Mädchenerziehung und höhere Töchterschule”. Paedagogium, 15. Leipzig: Klinkhardt, 303-314.

KALEPKY, Felix (1890). Warum und auf welche Weise werden in der höheren Mädchenschule fremde Sprachen gelehrt? Schulpro-grammschrift Städtische Höhere Mädchenschule Kiel.

KREYENBERG, Gotthold (1887). Die deutsche höhere Mädchenschule. Geschichte und Entwicklung derselben bis in die neueste Zeit. Frankfurt: Diesterweg.

MAASS, Adolf Eduard (1872). "Welches ist die Eigenart der weiblichen Natur und Bestimmung und wie ist darnach der Unterricht in der höheren Töchterschule zu gestalten?"

Vierteljahresschrift für Töchterschulen und Frauenbildung, 6, 193-257.

NIEMEYER, Georg Friedrich ( $\left.{ }^{5} 1918\left[{ }^{1} 1794\right]\right)$. Vermächtnis von Helene von ihrem Vater. $5^{\text {th }}$ edition 1918. Frankfurt a.M.: Wilmans.

NIMMERJAHN, Hermann (1898). "Soll Französisch oder Englisch in einer einsprachigen Mittelschule gelehrt werden?” Die Mittelschule und höhere Mädchenschule, 12, 441-448, 464-466.

REUTER, D. (1811). Pädagogisches Real-Lexicon oder Repertorium für Erziehungs- und Unterrichtskunde und ihre Literatur. Nürnberg: Campe. 
RITTER, Bernhard (1897). Erziehungs- und Unterrichtslehre für höhere Mädchenschulen. Weimar: Böhlau.

SANDER, Ferdinand (21889) (dir.). Lexikon der Pädagogik. Handbuch für Lehrer und Erzieher, enthaltend das Ganze des Unterrichts- und Erziehungswesens in kurzer, alphabethisch geordneter Übersicht. Zweite, durchgesehene und vermehrte Auflage. Breslau: Königliche Universitäts- und Verlagsbuchhandlung.

SCHUMANN, Johann Christian Gottlob (1876). “Über den Kosmopolitismus der modernen Bildung”. Zeitschrift für weibliche Bildung, 4, 604-607.

STRACK, Karl (1879). Geschichte der weiblichen Bildung in Deutschland. Gütersloh: Bertelsmann.

WENDT, Ferdinand Maria (1887). Psychologische Methodik des Mädchenunterrichts. Leipzig: Böhme.

\section{Secondary Sources}

ALBISETTI, James C. (1988). Schooling German Girls and Women. Secondary and Higher Education in the $19^{\text {th }}$ Century. Princeton: Princeton University Press.

DOFF, Sabine (2002). Englischlernen zwischen Tradition und Innovation. Fremdsprachenunterricht für Mädchen im 19. Jahrhundert. München: Langenscheidt-Longman.

DOFF, Sabine (2005). "Der Beitrag der neueren Fremdsprachen zur Konstituierung der deutschen höheren Mädchenschule”. In Werner Hüllen \& Friederike Klippel (dir.), Sprachen der Bildung Bildung durch Sprachen im Deutschland des 18. und 19. Jahrhunderts. Wiesbaden: Harrasowitz, 261-287. DOFF, Sabine (2008). "Was von Visionen übrig bleibt: Frauen, die neusprachliche Reformbewegung und ihr Echo im frühen 20. Jahrhundert.” In Sabine Doff, Werner Hüllen \& Friederike Klippel (dir.). Visions of Languages in Education. München: Langenscheidt ELT, 169-179.

HAAS, Renate (2000). "Eine vernachlässigte Grundfrage: Was bedeute(te)n Englischkenntnisse für deutsche Mädchen und Frauen?” In Helmut Schrey (dir.). Anglistik - quo vadis? Plädoyer für einen stärkeren Adressatenbezug. Essen: Die blaue Eule, 71-89.

HARDACH-PINKE, Irene (1993). Die Gouvernante. Geschichte eines Frauenberufs. Frankfurt a.M./New York: Campus.

\section{NOTES}

\section{1.}

This contribution is the revised written version of a paper presented at the 2012 congress of the GMF (Gesamtverband Moderne Fremdsprachen), section 1: "French, German and English in competition between 1850 and $1945^{\text {" (13 }}$ (h $^{\text {th }}$ September 2012).

1. Transl. SD. The original reads: "Auffällig ist es, daß das Sprachgedächtnis des weiblichen Geschlechtes, insofern es sich auf den Wort- und Wortformenschatz fremder Sprachen bezieht, sich sehr entwickelt zeigt. Es ist eine allgemein bekannte Thatsache, daß die Mädchen sich die modernen Sprachen schneller aneignen als Männer und Knaben. Letztere bringen es im Französischen und Englischen bei gleicher Begabung in der Regel nicht so weit."

2. Among them the "father" of the Reform Movement in Germany, Wilhelm Viëtor; for more details see footnote 8 .

3. Transl. SD. The original reads: "Man begnügt sich fast nirgends mehr mit der Erlernung einer fremden Sprache; das Französische und das Englische wird von allen Mädchen, die irgendwie auf Bildung Anspruch machen wollen, gefordert." 
1. This paper focuses on subject- and gender-related motives of this debate and does not take into account components of social and educational politics, which of course have to be considered when looking at this controversy and its agents in a broader context (for more details, Doff 2002).

2. Transl. SD. The original reads: "Fast ebenso sicher zeigt sich das schnelle Sprechtempo der Frauen bei den mongolenähnlichen Völkern und Negern, sowie bei den Polynesiern und Melanesiern. Es werden wahrscheinlich auch die Frauen der Australier und Buschmänner nicht ausgeschlossen sein, deren eigenartige Lebhaftigkeit und exzessive Art im Zustande des Affektes dem weiblichen Geschlechtscharakter im allgemeinen vollkommen entspricht."

3. Transl. SD. The original reads: "Ist ja doch in der Weiblichkeit das Gemüthliche mehr vorherrschend, und die Natur selbst sucht alles von dem weiblichen Wesen fernzuhalten, was seine Natürlichkeit zerstören könnte [...]. Dies ist der Grund warum beinahe so wenig bei der Grammatik Glück und Segen für das Mädchen ist, als bei der Mathematik; es liebt auch in der Sprache nicht den Begriff. Man soll daher den Sprachunterricht der Mädchen mehr lebendig betreiben, und da sie allerdings auch nie Regeln fassen sollen, so mache man diese nur so anschaulich als möglich. Aber das kann ja alles gewiß nur in der Muttersprache geschehen, und dann wohl auch in einer anderen, aber gewiß nur in einer lebendigen, die als lebendige gelernt wird."

4. This approach is summarized here and discussed in more detail in Doff (2002: 386-390). Many of the features analyzed in this context can also be found in the didactic program of the neusprachliche Reformbewegung (Reform Movement). This remarkable overlap is hardly surprising since a number of leading reformers taught modern languages at higher secondary schools for girls - yet this fact is usually overlooked when their innovative ideas are appreciated. It could thus easily be argued that higher secondary schools for girls were a predecessor for the Reform Movement or at least an experimenting ground for some of its main figures, like, for example, Julius Bierbaum, professor at a higher secondary school for girls in Karlsruhe, Jakob Wychgram, director of the Augusta-Schule in Berlin and the Reform Movement's probably most popular author Wilhelm Viëtor, who started his teaching career at a higher secondary girls school in Essen (Doff 2002: 400-415; Doff 2008).

5. Transl. SD. The original reads: "In Methode und Begrenzung einzelner Lehrstoffe nähert [die höhere Mädchenschule] sich der Elementarschule, in fremdsprachlicher Beziehung aber [...] hat sie mehrfache Berührung mit höheren Schulen."

6. Transl. SD. The original reads: "Sprachen bringen uns den Entwicklungsgang der menschlichen Vorstellungen zum Bewußtsein, den Begriffsreichthum des Menschen und die Nüancierung dieser seiner Begriffe, sowie ihre innere Verwandtschaft und ihren Bilderreichthum, und die Vergleichung der verschiedenen Sprachen dient dazu, sich der mannigfaltigen Ausgestaltung, welche eine und dieselbe Vorstellung bei den verschiedenen Völkern erhalten hat, bewußt zu werden. Endlich gewährt das Sprechen und Hören der Sprachen, namentlich der fremden, eine vortreffliche Uebung der Sprech- und Gehörorgane, sowie des Auffassungsvermögens."

7. Transl. SD. The original reads: "Sehen wir [...] in der Toleranz eines der schönsten Kennzeichen moderner Bildung, so ist überhaupt in jetziger Zeit ein sich Beschränken auf das dem eignen Volke Angehörige auf keinem Gebiet mehr möglich [...]. Der moderne Mensch muss in gewissem Sinn Kosmopolit sein und ist es auch faktisch [...]."

1. Transl. SD. The original reads: "[Es] lässt sich [...] nicht verkennen, dass die schablonenhaften, oft rein äußerlichen Regeln nichts weniger sind, als ein logisches Bildungsmittel, und dass diejenigen Geistesgaben, die bei der Frau hervorragend und charakteristisch sind, Urtheil und Geschmack, schnelle Auffassung, durch das Eintrichtern der französischen Grammatik nicht ausgebildet, sondern durch die Überlastung des Gedächtnisses, das in der Regel bei den Frauen von geringerer Stärke ist als bei den Männern, in ihrer Entwickelung gelähmt werden. Also vieles 
Lesen, häufige Übung in Schreiben und Conversation; dagegen Grammatik nur, soweit es nöthig ist, und mehr durch Übung als durch Auswendiglernen und Einpauken der Regeln!"

2. Transl. SD. The original reads: "[...] die französische Litteratur neben vielem Trefflichem recht viel Oberflächliches enthält, daß namentlich in den neueren Erzeugnissen hier eine Lebensauffassung und noch dazu in oft recht glänzendem Gewande uns entgegentritt, von der wir nicht wünschen, daß sie im deutschen Frauengemüte Wurzel fasse."

3. Transl. SD. The original reads: "[...] Das Französische ist das Latein der Töchterschulen."

4. Transl. SD. The original reads: "Keine unter allen neueren Sprachen hat gerade durch das Aufgeben und Zerrütten aller Lautgesetze, durch den Wegfall beinahe sämmtlicher Flexionen eine größere Kraft und Stärke empfangen als die englische, und von ihrer nicht einmal lehrbaren, nur lernbaren Fülle freier Mitteltöne ist eine wesentliche Gewalt des Ausdrucks abhängig geworden, wie sie vielleicht noch nie einer anderen menschlichen Zunge zu Gebot stand. Ihre ganze überaus geistige, wunderbar geglückte Anlage und Durchbildung war hervorgegangen aus einer überraschenden Vermählung der beiden edelsten Sprachen des späteren Europa's [...]."

1. Transl. SD. The original reads: "Wir sehen also, daß beide Sprachen hinsichtlich ihres gesamten Bildungswertes im großen und ganzen gleichberechtigt nebeneinander stehen. Wenn sie nebeneinander betrieben werden, ergänzen sie sich glücklich, indem der Verstand hauptsächlich durch das Französische, das Gemüt durch das Englische gebildet wird.”

\section{RÉSUMÉS}

L'article suivant a pour objectif principal d'analyser le rôle essentiel joué par l'anglais en tant que matière scolaire dans l'établissement d'un système d'enseignement secondaire public pour filles en Allemagne pendant le dernier tiers du $19^{\mathrm{e}}$ siècle. Il s'agissait d'un programme distinct pour les apprenantes qui allait souvent de pair avec un concept didactique spécifique correspondant d'une part, mais contrastant d'autre part, avec les standards développés en français, matière qui avait occupé une place prépondérante jusqu'alors. Au tournant du siècle, vers la fin du mouvement réformiste, c'est donc l'anglais qui a pris cette position dominante dans l'enseignement des langues modernes pour les filles. En partant d'articles de revues spécialisées contemporaines et de programmes scolaires, l'article présente une analyse critique de l'approche théorique et des conceptions de l'enseignement des langues modernes (concernant l'anglais en particulier) dans les écoles secondaires pour filles.

This paper focuses on the role which English as a school subject (and its specific didactic profile) played in the process of establishing a state system of higher secondary education for girls in Germany during the last third of the $19^{\text {th }}$ century. Distinct contents for female learners often went hand in hand with a specific methodological design which partly matched and partly contrasted with the standards developed for French, the subject which had so far dominated the field. English soon took over the "pole position" in modern language teaching for girls around the end of the century during the period of the Reform Movement. The paper presents a critical analysis of the approach and design of teaching modern languages (in particular English) at higher secondary schools for girls and the motives for doing so, mainly based on articles in contemporary journals and school program papers. 
INDEX

Keywords : Higher secondary schools for girls, German school system (19th century, Genderspecific pedagogy, Language teaching methodology, Reform Movement (of modern language teaching)

Mots-clés : enseignement secondaire des filles, système scolaire allemand (XIXe siècle, pédagogie de l'éducation des filles, méthodologie de l'enseignement des langues, oouvement réformiste (de l'enseignement des langues modernes)

\section{AUTEUR}

\section{SABINE DOFF}

Universität Bremen, Germany

doff@uni-bremen.de 